\title{
Physicochemical Properties, Nutritional and Sensory Quality of "Batuan" [Garcinia binucao (Blco.) Choisy] Fruits
}

\section{Elizabeth S. Quevedo ${ }^{1}$, Antonio C. Laurena ${ }^{2}$ and Florinia E. Merca $^{3}$}

${ }^{\prime}$ Department of Pure and Applied Chemistry, Visayas State University, Baybay City, Leyte 6521-A Philippines, ${ }^{2}$ Institute of Plant Breeding, Crop Science Cluster, University of the Philippines Los Baños, Los Baños, Laguna, ${ }^{3}$ Institute of Chemistry, University of the Philippines Los Baños, Los Baños, Laguna

\begin{abstract}
The physicochemical properties and nutritional profile of the different parts and stages of maturity of "batuan" [Garcinia binucao (Blco.) Choisy] fruits in the Visayas State University (VSU) were determined using standard analytical methods to validate their use as a safe food ingredient. Sensory evaluation on the acceptability of the dry, powdered "batuan" fruits as souring agent in fish stew dish was also conducted.

Proximate composition, physicochemical properties and nutrient composition between parts and fruit maturity varied to some level. The pulp which constituted the biggest part of the fruit and the immature ones contained high moisture and acidity that decreased as the fruit matured. Ash, protein, sugar, starch, total carbohydrates, total soluble solids, and sodium content were low in "batuan" fruits. The seeds contained high crude fat, crude protein, and tannin. "Batuan" fruits were also found high in vitamin $\mathrm{C}$, potassium, phosphorus, calcium, magnesium, iron, and trace levels of zinc, copper and manganese. Crude fiber and vitamin A were concentrated in the peel, pulp and ripe fruit. Based on the 9-point Hedonic scale for sensory evaluation, the fresh and the dry, powdered "batuan" fruits were comparable to one another in terms of color, mouth feel, taste and general acceptability as souring agent for fish stew.

Results showed that "batuan" fruits have good physicochemical properties and nutrient contents which are comparable or even higher than some conventional fruits used as souring agents. The powdered "batuan" fruit is a potential ready-touse souring agent for domestic consumption, food industry, and other applications.
\end{abstract}

Keywords: batuan, Garcinia binucao (Blco.) Choisy, minerals, vitamin content, general acceptability

Correspondence: E. S. Quevedo. Address: Department of Pure and Applied Chemistry, Visayas State University, Visca, Baybay City, Leyte, Philippines. E-mail:elizabethquevedo48@yahoo.com. Tel. No. +63535637870

DOI: 10.32945/atr3521.2013 


\section{INTRODUCTION}

Nutrients necessary for healthy life and growth are generally derived from domesticated or wildly-grown plants or animals. In the Philippines, diverse, edible, and lesser-known indigenous fruits that abound in the wild are underutilized due to their unknown features and are popular only among the local people. With the global food scarcity and current push for the use of indigenous food sources for conservation and potential product development, there is a need to investigate some indigenous fruits that are not popularly known and consumed.

The Gutifferae family includes a wide range of tree species with approximately 50 genera and 1200 species (Paull and Duarte, 2012). Some of them are very popular, have potential or economic significance, and are extensively used for their medicinal value. "Batuan" [Garcinia binucao (Blco.) Choisy](Gutifferae) is one of the indigenous, lesser-known, edible fruit-bearing tree that is widely distributed throughout the Philippines and Vietnam (Verheij and Coronel, 1999; Department of Agriculture of the Philippines, 1995). In the Philippines, "batuan" trees are grown scattered in primary, low and medium altitude forests throughout Luzon, specifically in Masbate; Mindanao and commonly found in the Visayas particularly in Panay, Negros Occidental, Guimaras Island, Leyte, Samar, Cebu and Bohol (de la Cruz, 2012; Florido and Cortiguerra, 2003). According to Florido and Cortiguera (2003), "batuan" has other names in other places such as "binukao" (Laguna and Bataan), "balukat" (Ilocos Norte), "bangkok" (Zambales), "bilukan" (Rizal), "kamangzi" (Tayabas) and "kandis" (Palawan).

Nowadays, "batuan" is gaining economic importance due to its sour fruit which is one of the 300 fruit species identified with commercial value and export potential when properly utilized (Coronel, 2011). Thus, it is being cultivated as a minor tree crop in home gardens and commercial scale at the Eduardo Cojuangco, Jr. (ECJ) Farm, an affiliate company of San Miguel Corporation, Candelaria, San Enrique, Negros Occidental for increase fruit production (Cojuangco, 2012; Valencia, 2013). Aside from its sour fruits, the trees are also grown as excellent wood sources, and as landscape trees. The fruit which is yellowish-green, somewhat rounded, $4 \mathrm{~cm}$ or more in diameter contains a very acidic pulp and several astringent seeds. Thus, the fruit is the favorite souring agent for stews and other authentic native dishes in lieu of the tamarind (Tamarindus indica L.) or kamias (Averrhoa 
Physicochemical properties of Batuan

bilimbi L.) by the local people especially in Negros Occidental, Iloilo, Panay, and some parts of Leyte and Samar (Reyes, 2011). The fruits could also be eaten fresh after washing with tap water and dipping on table salt (Cojuangco, 2012). During peak season, "batuan" fruits which command as high as P30-40 a kilo can likewise be made into various commercial products such as salted puree, jam, dried prune, jelly, and candies (Cojuangco, 2012; Tajanlangit, 2011; Department of Agriculture of the Philippines, 1995; Anonymous, 2006). Moreover, the "Batuan" Puree of the ECJ Farms, Inc. has been transported to the US and Europe for Filipinos longing for the unique batuan flavor at home.

Despite its economic importance, "batuan" fruit has not received much attention among business entrepreneurs and the scientific community. This may be due to lack of nutritional information, and its seasonal fruiting pattern which limits the prospects of research studies and utilization. In the Philippines, data on its physicochemical properties, nutrient contents, production and yield are not available. Just like its high-valued, close relative, mangosteen (G. mangostana), "batuan" fruit may have components such as plant protein, dietary fiber, tannins and micronutrients that may be beneficial for health. In this study, the characteristics of the different parts and stages of maturity of "batuan" fruit in terms of the physical properties, proximate composition, mineral content, vitamins, tannin content, $\mathrm{pH}$, titrable acidity, and total soluble solids were determined using standard analytical methods to validate its use as a safe food ingredient and for other industrial applications. The sensory attributes of the fresh and the dry, powdered "batuan" fruits as souring agent in fish stew or "sinigang" dish were also evaluated using the 9-point Hedonic scale.

\section{MATERIALS AND METHODS}

Reagents and chemicals. Pure standards of L-ascorbic acid, and gallic acid were purchased from SIGMA-ALDRICH (St. Loius, MO, USA). All other reagents used were of analytical grade.

Collection of batuan fruit samples and preparation of samples. "Batuan" fruits were harvested from the Pomology Project of the Department of Horticulture and low mountainous area of the Visayas State University (VSU), Baybay City, Leyte, Philippines on June 2012. The fruits were authenticated from the University of the Philippines Los Baños (UPLB) Museum of Natural History, College, Laguna, Philippines. 
Immediately after collection, disease-free "batuan" fruits were washed with tap water and air-dried. Composite samples representing the peel, pulp, and the seeds (endosperm) of the mature fruits as well as whole immature, mature and ripe fruits were prepared. The fruits were classified into three stages of maturities according to their firmness, skin/pulp color, aroma and comparison on cross-section of the fruits (Table 1).

Table 1. State of maturity of "batuan" [G. binucao (Blco.) Choisy] fruit.

\begin{tabular}{ll}
\hline Maturity & Fruit Color and State of Maturity \\
\hline Immature & $\begin{array}{l}\text { light green, firm, thin skin; white and watery pulp; soft } \\
\text { pericarp, watery and less than half-endosperm filled seeds }\end{array}$ \\
Mature & $\begin{array}{l}\text { green, firm, thin skin; creamy white and less watery pulp; } \\
\text { thick, woody-hard pericarp; more than half-endosperm } \\
\text { filled and fully developed endosperm }\end{array}$ \\
& $\begin{array}{l}\text { light yellow, soft skin and pulp; thick, woody- hard pericarp; } \\
\text { Ripe }\end{array}$ \\
\hline
\end{tabular}

All samples were dried at 70C for 16 hours using a fabricated food cabinet dryer at the Department of Food Science and Technology (DFST), VSU. The dried samples were ground into powder using homogenizer/blender (Osterizer), passed through a 60-mesh sieve, stored in an air tight plastic container (Ziploc) and kept at room temperature.

Physical characteristics analysis. For the analysis of physical characteristics, only the mature fruits were considered. Ten mature fruits were individually analyzed for their weight, width, percentage composition (by weight) of the different parts of the fruit, and number of seeds per fruit. Weight of 100 dry seeds were also obtained.

Proximate composition and mineral analyses. Moisture content, crude protein as well as total sugar, total starch, and mineral contents were analyzed at the Central Analytical Service Laboratory, PhilRootcrops, VSU using standard methods for plant tissue samples. The crude fat and crude fiber analyses were done at the Animal Nutrition Research Laboratory (II), UPLB using standard AOAC methods (AOAC, 1980). 
Physicochemical properties analyses. Titrable acidity (TA), $\mathrm{pH}$, and total soluble solids (TSS) were done using standard AOAC methods (AOAC, 1980) at the Analytical Service Laboratories (ASL), Institute of Plant Breeding (IPB), UPLB; the Philrootcrops and the Department of Pure and Applied Chemistry (DoPAC), VSU, respectively. Titrable acidity of the samples was computed based on citric acid which is the most abundant and exists in greater than trace amounts in a variety of fruits and vegetables.

Vitamin A, C and Tannin Content. Vitamin A (beta-carotene), vitamin C and tannin content were determined colorimetrically using the AOAC method (AOAC, 1980), 2,6-dichlorophenolindophenol dye method (AOAC method as adapted by the JT Baker Chemical Company, Philsburg, NJ) and the modified vanillin method following the protocol of Sun et al. (1998), respectively at the ASL of IPB, UPLB.

Sensory evaluation. For the sensory evaluation, only the fresh and dry, powdered immature and mature "batuan" fruits were considered and used as souring agent in the fish "sinigang" dish. The sensory attributes tested included color, mouth feel, aroma, taste, flavor and overall acceptability using a score sheet with 9-point Hedonic Scale and employing 48 Food Science \& Technology (FST) major students/faculty/staff from the DFST, VSU who had classroom training and were always involved in sensory evaluation. Sensory evaluation data were analyzed using the Incomplete Block Design (IBD) by Cochran and Cox (1957) and SPSS software version 2.

Statistical analyses. All analyses were done in triplicate and results were expressed as means \pm standard deviation. Results of the chemical, and physicochemical tests of the batuan samples were statistically analyzed and compared using one-way Analysis of Variance (ANOVA) with statistical significance for difference set at $p<0.05$, followed by Least Significant Differences test (LSD) at $\alpha=0.05$ to locate significant differences for significantly different treatment effects.

\section{RESULTS AND DISCUSSION}

\section{Physical and Chemical Properties}

Physical characteristics. Results showed that the indigenous "batuan" fruits (Table 2 and Fig. 1) used in this study were smaller ( $44.5 \pm 0.75 \mathrm{~mm}$ in 
diameter) compared to the reported 40-70.5 mm diameter for "santol" (Sandoricum koetjapi Merr.) fruit (Morton, 1987). Additionally, the pulp made up the greater part of the fruit $(64.56 \pm 9.02 \%)$, followed by the seeds $(29.77 \pm 7.16 \%)$, and the peel $(5.67 \pm 2.18 \%)$. "Batuan" fruits also contained more seeds $(7 \pm 1.89)$ than the "santol" fruits (3 to 5 seeds). Moreover, 100 dry seeds of "batuan" weighed $96.16 \pm 6.69 \mathrm{~g}$.

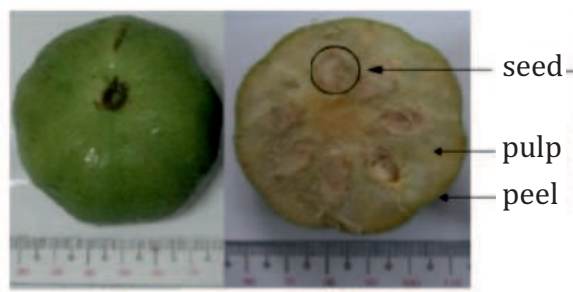

(A)

(B)

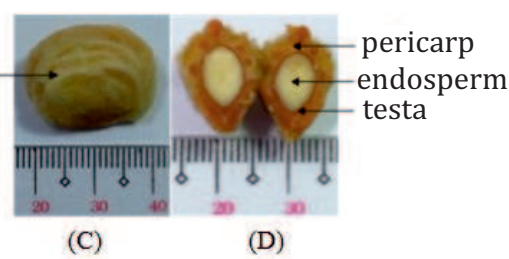

(D)

Fig. 1. Photographs of the plant materials used in this study. (A) The "batuan" fruit; (B) Cross-sectional view of the fruit; (C) The seed; (D) Cross-sectional view of the seed

Table 2. Physical characteristics of "batuan" [G. binucao (Blco.) Choisy] fruit grown at VSU, Baybay City, Leyte.

\begin{tabular}{cc}
\hline Characteristics & Value $^{\mathbf{1}}$ \\
\hline Whole fruit & \\
Weight $(\mathrm{g})$ & $55.0 \pm 11.4$ \\
Width $(\mathrm{mm})$ & $44.5 \pm 7.5$ \\
Percentage amount of peel & $5.67 \pm 2.18 \%$ \\
Percentage amount of pulp & $64.56 \pm 9.02 \%$ \\
Percentage amount of seeds & $29.77 \pm 7.16 \%$ \\
No. of seeds per fruit & $7 \pm 1.89$ \\
weight $(\mathrm{g}) / 100$ dry seeds & $96.16 \pm 6.69$ \\
\hline $1 \mathrm{n}=10$ &
\end{tabular}

Proximate composition. Table 3 shows that the proximate composition (dry weight basis) of the different parts and stages of maturity of "batuan" fruits varied to some extent. Among the different parts of the "batuan" fruit, the pulp had the highest moisture $(83.55 \pm 0.29 \%)$ followed by the peel $(77.90 \pm 0.36 \%)$ and seeds (endosperm) $(50.50 \pm 2.40 \%)$. In terms of fruit maturity, the immature fruit had the highest moisture $(85.77 \pm 0.31 \%)$ compared to that of the mature $(71.98 \pm 1.94 \%)$ and ripe $(73.17 \pm 0.27 \%)$ 
fruits. The high moisture content of the immature fruit is comparable to the reported $85.4 \%$ for S. koetjapi Merr. (Morton, 1987) and this was expected as the fruit was not yet fully developed. Additionally, the generally high moisture content in "batuan" fruits signifies its susceptibility to microbial deterioration and less storability under ambient condition. Meanwhile, the ash content of "batuan" fruits was generally low (ranging from 1.75 $\pm 0.15 \%$ to $3.90 \pm 0.10 \%$ ) and is comparable to $2.27-5.37 \%$ for the dried seeds of Tamarindus indica L. (Adeola et al., 2012). The peel had the highest ash value $(3.90 \pm 0.10 \%)$ suggesting a high mineral content.

The crude protein content of "batuan" fruit samples was similarly low (less than 10\%) with the reported $7.64 \%$ for the dried T. indica L. pulp (Adekunle \& Adenike, 2012) and the 2.8-5.5g $100 \mathrm{~g}^{-1}$ edible portion of Psidium guajava L. but higher compared to the reported $0.61 \%, 0.06 \%$ and $0.86 \%$ for Averrhoa bilimbi L., S. koetjapi Merr. and Citrofortunella microcarpa (Morton, 1987), respectively. The higher crude protein content obtained in the seeds of "batuan" fruit $(8.92 \pm 0.59 \%)$ is comparable to reported 6.50-9.37\% for the T. indica L. seeds (Adeola et al., 2012). The low protein content in "batuan" samples suggests that the fruits are not very suitable for improvement of nutritional values and replenishment in children and adult but could be an inexpensive addition to the body's protein requirement.

Crude fat which is a common index of nutritional quality was not detected in the pulp, peel and immature fruit but found high in the seeds $(54.72 \pm 0.34 \%)$ whose value is even higher compared to those reported $21.18 \pm 6.18 \mathrm{~g} 100 \mathrm{~g}^{-1}$ for $G$. mangostana (Ajayi et al., 2013), 20-24\% dry basis for Moringa oleifera Lamk. (Yap, 2011 unpublished BS thesis),

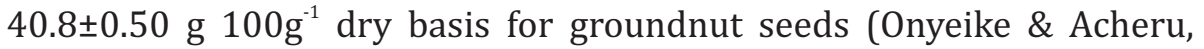
2002), 17.0-21.0\% for soybeans (Pritchard, 1991), 34\% for coconut (Canapi et al., 2005), 42\% for palm kernel oil (Atashi and Akinhanmi, 2009), $1.03 \%$ for dried T. indica L. pulp (Adekunle \& Adenike, 2012) and $15.70-18.67 \%$ for seeds (Adeola et al., 2012), 2.41\% for C. microcarpa and $1.43 \%$ S. koetjapi Merr. (Morton, 1987). Thus, it is suggested that fat is the most abundant macronutrient in the seeds (endosperm) of "batuan" fruit, which contributes to a higher calorie content and promotes absorption of fat-soluble vitamins when incorporated in the diet. Moreover, the high crude fat content of batuan seeds also enhances the market value of the fruit by serving as possible raw material for making soap, paint, polish, wood varnish, skin cream and other food applications.

"Batuan" fruits are also good sources of fiber with higher values 
obtained in the peel $(14.61 \pm 0.39 \%)$, pulp $(12.32 \pm 0.24 \%)$, immature $(17.36 \pm 0.10 \%)$, mature $(19.19 \pm 0.33 \%)$ and ripe fruits $(15.11 \pm 1.01 \%)$. The high crude fiber content in "batuan" fruits is generally comparable to the reported 2.2-18.3\% for dried tamarind pulp (Coronel, 1991; Feungchan et al. 1996 \& 1996b) and higher than those reported $0.6 \%$ for $A$. bilimbi L. and $1.26 \%$ for S. koetjapi Merr. (Morton, 1987). Furthermore, these results reinforce the idea that "batuan" fruit should be consumed unpeeled since it provides a higher source of dietary fiber that helps regulate bowel movement and aids in constipation. Aside from being a good source of crude fiber, "batuan" fruits also contain low total sugar and carbohydrate making it a good food for people on diet. In terms of fruit parts, the seeds (endosperm) had a significantly higher total sugar $(15.11 \pm 1.01 \%)$ content than the peel $(7.28 \pm 0.24)$ and the pulp (3.43 $\pm 0.19 \%$ ). Furthermore, the total sugar increases from $3.94 \pm 0.35 \%$ (immature fruit) to $10.18 \pm 0.15 \%$ (ripe fruit) as the fruits mature due to the conversion of starch to sugars. In addition, the total carbohydrates obtained for the immature fruit was low $(11.39 \pm 0.76 \%)$ while the mature $(21.02 \pm 1.45 \%)$ was significantly higher than that of the ripe fruits $(19.28 \pm 1.28 \%)$ and the peel $(18.27 \pm 0.68 \%)$. Generally, the total carbohydrates content in "batuan" fruits was low compared to $56.0 \%$ for dried tamarind pulp (Adekunle \& Adenike, 2012). Furthermore, there are no previously reported data on the chemical analysis of the different parts and stages of fruit maturity of $G$. binucao in the Philippines and from other countries to compare the results of this present work.

Mineral content. Table 4 shows that "batuan" fruits used in this study are good sources of metabolically important minerals such as potassium, calcium, magnesium, phosphorus, iron and sodium and trace elements such as copper, zinc and manganese for the metabolic activities in living tissues (Gorinstein et al., 2001). Table 4 shows that among the different parts of the fruit, the peel was significantly high in potassium $(12,010.24$ $\left.\mathrm{mg} \mathrm{kg}{ }^{-1}\right)$, calcium $\left(2,944.88 \pm 414.15 \mathrm{mg} \mathrm{kg}^{-1}\right)$, iron $\left(199.28 \pm 18.75 \mathrm{mg} \mathrm{kg}^{-1}\right)$ and manganese $\left(34.58 \pm 0.44 \mathrm{mg} \mathrm{kg}^{-1}\right)$. Potassium is useful in the maintenance of a healthy nervous system and in balancing the body's nervous system. Calcium and magnesium are essential for bone development and for energy metabolism. Iron is essential for the production of red blood cells which carry all the nutrients to cells throughout the body. Moreover, the seeds (endosperm) are good sources of phosphorus $\left(243.56 \pm 22.64 \mathrm{mg} \mathrm{kg}^{-1}\right)$ and magnesium $(677.86 \pm 263.71$ 


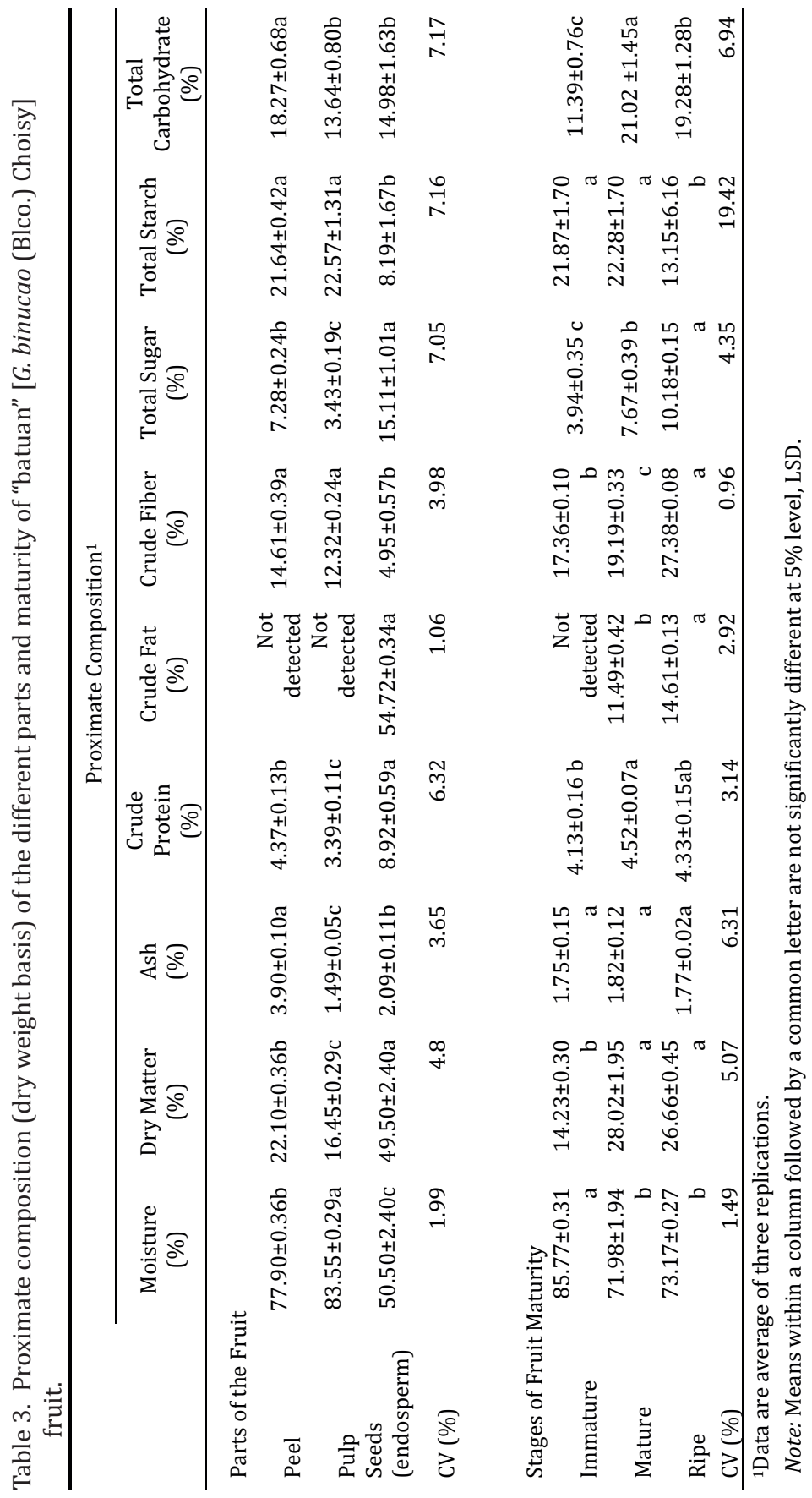




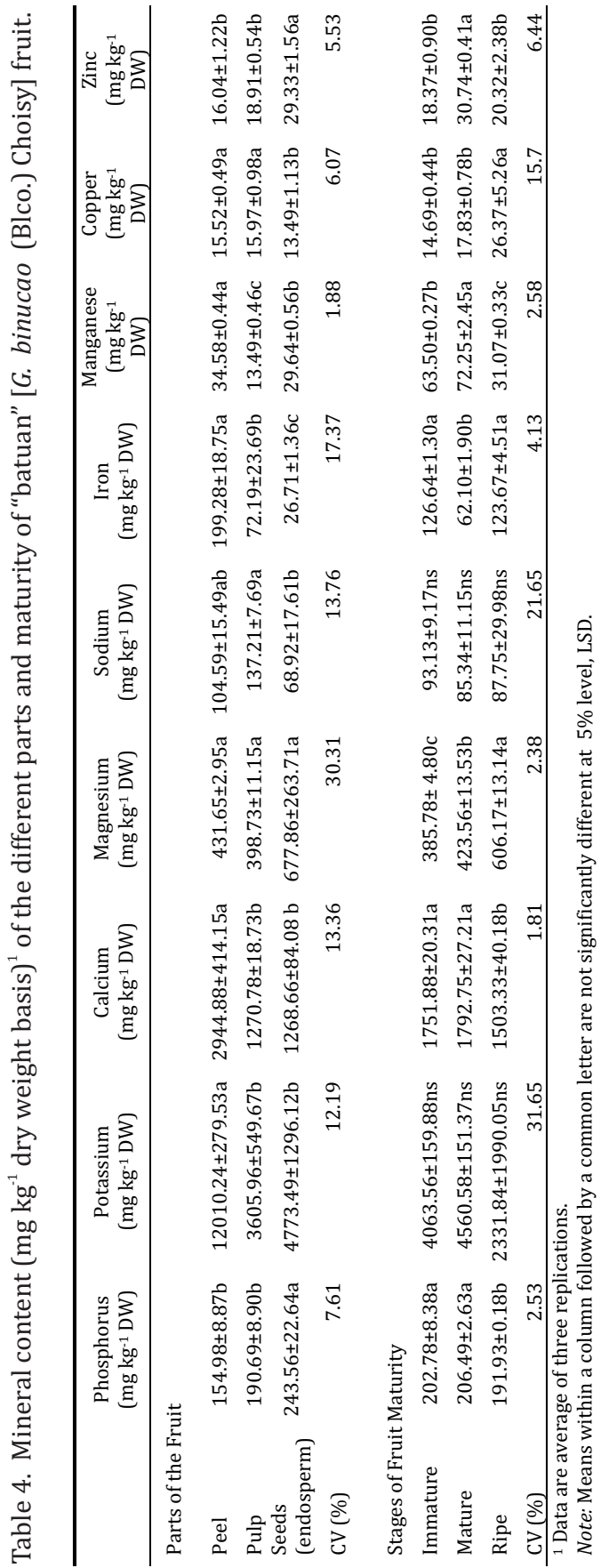


$\left.\mathrm{mg} \mathrm{kg}{ }^{-1}\right)$. The peel and the pulp had similarly higher content of sodium (104.59 $\pm 15.49 \mathrm{mg} \mathrm{kg}^{-1}$ and $137.21 \pm 7.69 \mathrm{mg} \mathrm{kg}^{-1}$, respectively), copper (15.52 $\pm 0.49 \mathrm{mg} \mathrm{kg}^{-1}$ and $15.97 \pm 0.98 \mathrm{mg} \mathrm{kg}^{1}$, respectively) and zinc (16.04 $\pm 1.22 \mathrm{mg} \mathrm{kg}^{-1}$ and $18.91 \pm 0.54 \mathrm{mg} \mathrm{kg}^{1}$, respectively).

In terms of fruit maturity, the immature and the mature fruits were similarly abundant in potassium $\left(4,063.56 \pm 159.88 \mathrm{mg} \mathrm{kg}^{-1}\right.$ and $4,560.58 \pm 151.37 \mathrm{mg} \mathrm{kg}^{-1}$, respectively)(Table 4). Aside from high level of potassium, the mature fruit also contained high calcium $(1,792.75 \pm 27.21$ $\left.\mathrm{m} \mathrm{kg}^{-1}\right)$, manganese $\left(72.25 \pm 2.45 \mathrm{mg} \mathrm{kg}^{-1}\right)$, and zinc $\left(30.74 \pm 0.41 \mathrm{mg} \mathrm{kg}^{-1}\right)$. On the other hand, iron was similarly high in the immature $(126.64 \pm 1.30$ $\left.\mathrm{mg} \mathrm{kg}^{-1}\right)$ and the ripe fruits $\left(123.67 \pm 4.51 \mathrm{mg} \mathrm{kg}^{-1}\right)$. In general, the sodium content in "batuan" fruits was quite low (ranging from 85.34+11.15 to $93.13+9.17 \mathrm{mg} \mathrm{kg}^{-1}$ ) which implies a low risk of heart disease and hypertension when consumption is high. Since the "batuan" fruits used in this study are rich in metabolically important mineral elements, a diet containing the fruit will help prevent mineral deficiency through regular consumption. However, as the mineral content in plants are known to be affected by several factors such as soil condition, weather conditions during growing, use of fertilizer and the state of fruit's maturity at harvest (Ekholma et al., 2007), the mineral profile of "batuan" fruits obtained in this study may not be the same for all the "batuan" fruits grown in other places. No previously reported data on G. binucao in the Philippines and from other countries exists so no comparison can be made.

$p H, T A$, and TSS of batuan fruit. The $\mathrm{pH}$, total acidity or titrable acidity and total soluble solids are important parameters that contribute to the determination of the fruit quality. The $\mathrm{pH}$ measures the hydrogen ion concentration in solution. Total acidity refers to the degree of sourness of a sample due to the total organic acids content. Total soluble solid is another expression for the dissolved sugars in a sample measured using a refractometer. The fruit of "batuan" varies significantly in terms of $\mathrm{pH}$ and titrable acidity at various parts and stages of maturity. Table 5 shows that among the different parts of the fruit, the pulp had the lowest $\mathrm{pH}$ $(1.44 \pm 0.01)$ and highest titrable acidity $(8.58 \pm 0.11 \%)$ suggesting that the pulp is the most acidic and sour compared to the peel $(\mathrm{pH}=1.99 \pm 0.01 ; \mathrm{TA}=$ $5.12 \pm 0.23 \%)$ and the seeds endosperm $(\mathrm{pH}=5.09 \pm 0.0 \mathrm{TA}=0.96 \pm 0.00 \%)$. In terms of fruit maturity, the immature fruit was the most acidic with lowest $\mathrm{pH}$ value $(1.54 \pm 0.01)$ and highest $\%$ titrable acidity $(7.04 \pm 0.29 \%)$ which differed significantly from those of the mature $\mathrm{pH}=1.88 \pm 0.06$ and 


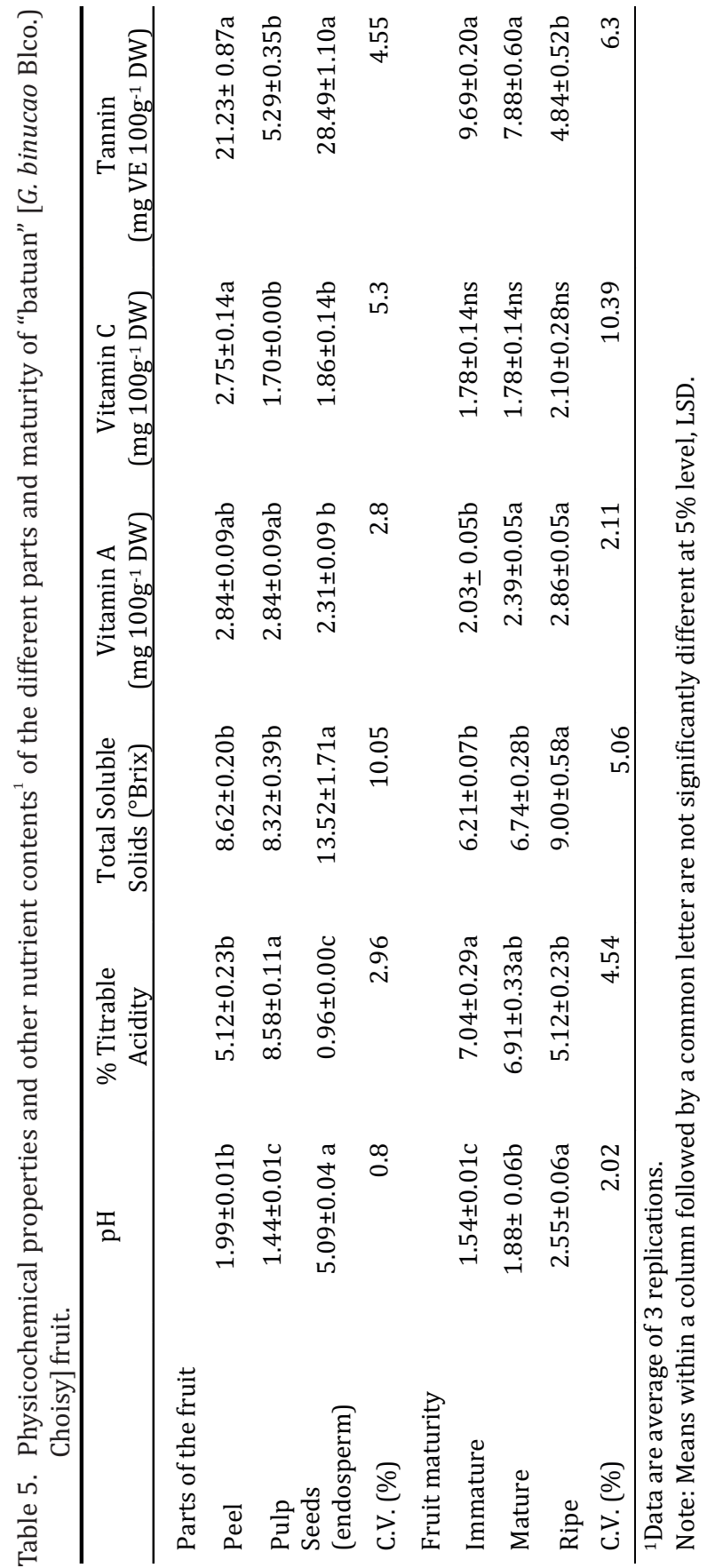


Physicochemical properties of Batuan

$6.91 \pm 0.33 \%$, respectively) and the ripe ( $\mathrm{pH}=2.55 \pm 0.06$ and $5.12 \pm 0.23 \%)$. Moreover, the $\mathrm{pH}$ of "batuan" fruits is generally lower compared to the reported 4.47 for A. bilimbi L. (Morton, 1987). The high acidity of "batuan" fruits implies the less occurrence of microbial spoilage and fermentation during processing. Furthermore, the high acidity of the immature fruits which declines as the fruit ripens is in agreement with the published data on A. carambola L. (Patil et al., 2010), strawberry (Voća et al., 2008) and "Maoluang" (Antidesma bunius L. Spreng) fruits (Butkhup and Samappito, 2011). A decrease in acidity was observed during ripening since the organic acids are generally metabolized and converted to sugar.

On the other hand, the total soluble solids in "batuan" fruits (6.21 $\pm 0.07-13.52 \pm 1.71 \mathrm{Brix}$ ) was comparable with the reported $7.0-12.5 \%$ for P. guajava L. (Kadam et al., 2012; Nakasone et al., 1967) but low compared to the reported $18-48^{\circ}$ Brix for fresh T. indica fruit (Kaur et al., 2006). In terms of parts of the fruit, the seeds (endosperm) exhibited the highest value $(13.52 \pm 1.71 \mathrm{Brix})$ and the pulp, the lowest ( $8.32 \pm 0.39 \mathrm{Brix})$. Meanwhile, the TSS values increased from $6.21 \pm 0.07 \mathrm{Brix}$ to $9.00 \pm 0.58 \mathrm{Brix}$ as the fruit matured suggesting an increase in dissolved sugars as the fruits ripened. The TSS values further support the obtained results of increasing total sugar as the fruit matures. The low level of total soluble solids which implies the presence of a low level of sugar suggests that "batuan" fruit is safe to be eaten by diabetic patients.

Vitamin A (beta-carotene), Vitamin C (ascorbic acid) and tannin content. Carotenoids act as quenchers of singlet oxygen, as antioxidants, in gene activation, and in inflammation and immune processes (Setiawan et al., 2001). Table 5 shows that the content (dry weight basis) of beta-carotene did not vary greatly among different parts and maturity of "batuan" fruits and were similarly low $\left(2.31 \pm 0.09 \mathrm{mg} 100 \mathrm{~g}^{-1}-2.84 \pm 0.09 \mathrm{mg} 100 \mathrm{~g}^{-1}\right)$. However, the obtained values for $\beta$-carotene in "batuan" fruits were higher compared to the reported 10-60 $\mu \mathrm{g} 100^{-1} \mathrm{~g}$ for dried T. indica L. pulp (Coronel, 1991) and $0.035 \mathrm{mg} 100 \mathrm{~g}^{-1}$ edible portion for A. bilimbi $\mathrm{L}$. (Morton, 1987).

In terms of vitamin $\mathrm{C}$ content, no significant differences were observed among the immature, mature and ripe fruits but differed in terms of fruit parts. The highest amount (dry weight basis) of vitamin $\mathrm{C}$ was obtained in the peel $\left(2.75 \pm 0.14 \mathrm{mg}_{\left.100 \mathrm{~g}^{-1}\right)}\right.$ which was higher than the reported $0.78 \mathrm{mg}$ $100^{-1} \mathrm{~g}$ edible pulp of $S$. koetjapi Merr. (Morton, 1987) but lower compared to the 3-9 mg $100^{-1} \mathrm{~g}$ for dried T. indica L. pulp (Coronel, 1991; Feungchan et al., 1996a \& 1996b), 9.5-18 $\mathrm{mg} \mathrm{g}^{-1}$ fresh weight of $A$. carambola L. (Patil et 
al., 2010), $45 \mathrm{mg} 100 \mathrm{~g}^{-1}$ for "calamondin" (Morton, 1987) and $190 \mathrm{mg} 100 \mathrm{~g}^{-1}$ edible portion of common P. guajava L. (Wenkam, 1990).

Table 5 shows the tannin content in "batuan" fruits was found similarly abundant (dry weight basis) in the endosperms $\left(28.49 \pm 1.10 \mathrm{mg} \mathrm{VE} 100 \mathrm{~g}^{-1}\right)$ and the peel $\left(21.23 \pm 0.87 \mathrm{mgVE} 100 \mathrm{~g}^{-1}\right)$. Nonetheless, the tannin content of the pulp of "batuan" fruit $\left(5.29 \pm 0.35 \mathrm{mg} \mathrm{VE} 100 \mathrm{~g}^{-1}\right)$ is comparable with the

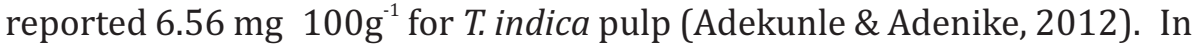
terms of fruit maturity, the immature ones had the highest tannin content $\left(9.69 \pm 0.20 \mathrm{mg} \mathrm{VE} 100 \mathrm{~g}^{-1}\right)$ which did not differ significantly with that of the mature $\left(7.88 \pm 0.60 \mathrm{mg} \mathrm{VE} 100 \mathrm{~g}^{-1}\right)$ fruits. High tannin content usually affects the digestibility of proteins, fats, carbohydrates as well as the bioavailability of minerals. The tannin content in the seeds, immature as well as the mature fruit will definitely affect the nutritive value of the food. On the positive side, it also makes the "batuan" fruit a good food ingredient that detoxifies ingested toxic metals and as a source of natural antioxidants.

Sensory evaluation and acceptability of the dried, powdered "batuan" fruit. Preliminary evaluations were carried out to determine the suitable level of "batuan" fruit samples and water in order to produce high quality fish stew with ideal sour taste. Results revealed that the broth prepared with $150 \mathrm{~g}$ to $200 \mathrm{~g}$ of fresh and dry, powdered immature and mature "batuan" fruits had the highest acceptability among the panelists. Thus, these levels were used in the succeeding preparations of fish stews.

Tables 6 and 7 summarize the mean scores for the sensory attributes and the sensory descriptions of the fish stews, respectively. Sensory analysis indicated that the color, mouth feel, taste and general acceptability did not differ significantly among the fish stews with and without "batuan" fruit samples. However, the fish stews differed significantly in terms of aroma and flavor. As more "batuan" fruits were used as souring agent in the fish stews, the more desirable aroma and flavor were perceived (Table 7), which could be due to the presence of natural aromatic and flavorenhancing compounds in the "batuan" fruits. Nonetheless, the fish stews with and without "batuan" fruits were rated with high general acceptability which is comparable to each other. The quality of the dried, powdered "batuan" fruits may be further improved by adding salt and protein concentrates.

\section{CONCLUSION}

Based on the results of the study, the proximate composition, 


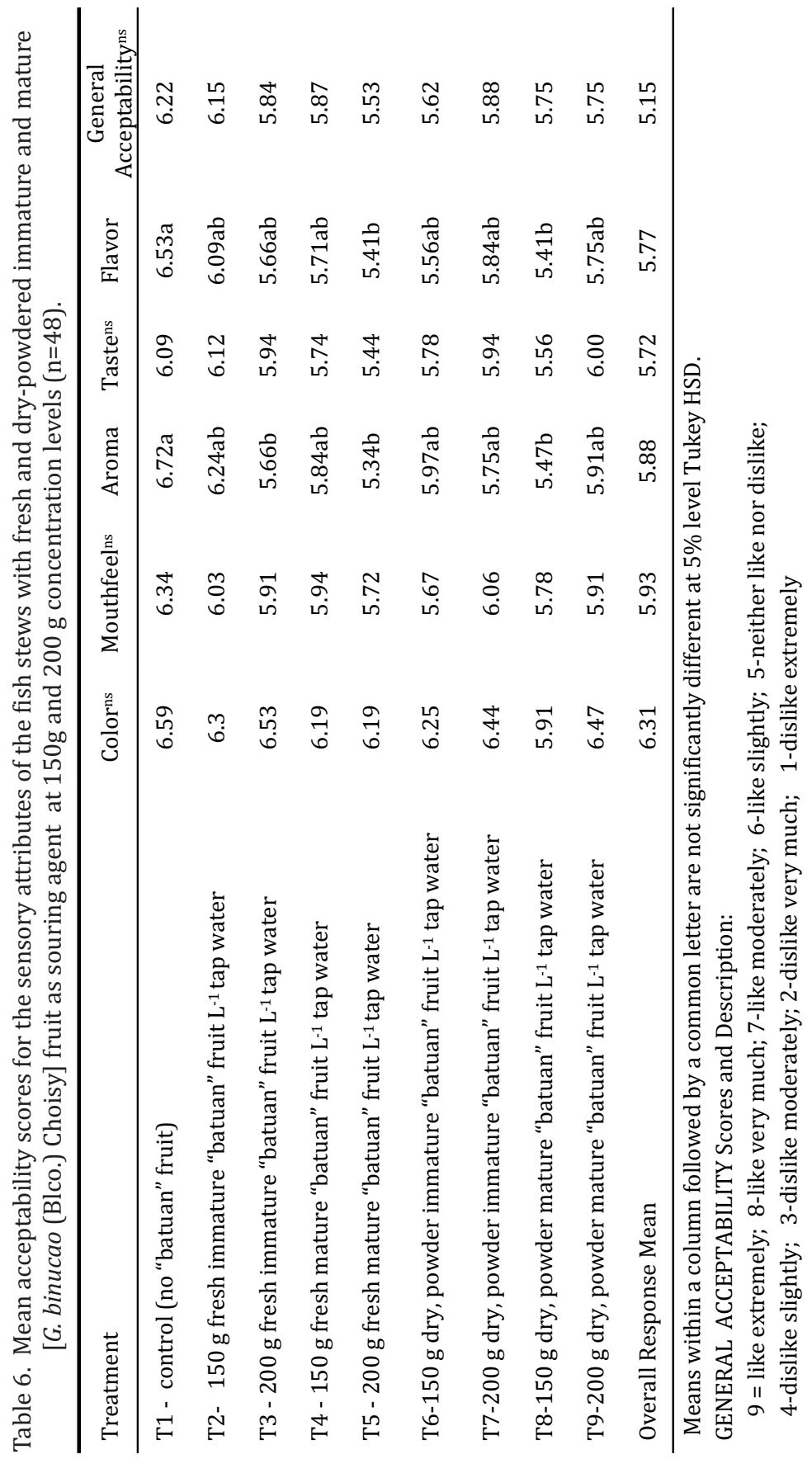


Table 7. Sensory description of the fish stews with fresh and dry-powder immature and mature "batuan" [G. binucao (Blco.) Choisy] fruit as souring agent at $150 \mathrm{~g}$ and 200 g concentration levels $(n=48)$.

\begin{tabular}{|c|c|c|c|c|c|c|}
\hline Treatment & Color & Mouthfeel & Aroma & Taste & Flavor & $\begin{array}{c}\text { General } \\
\text { Acceptability }\end{array}$ \\
\hline $\begin{array}{l}\text { T1 -no "batuan" } \\
\text { fruit }\end{array}$ & $\begin{array}{l}\text { Pale } \\
\text { olive } \\
\text { green }\end{array}$ & $\begin{array}{l}\text { Slightly } \\
\text { perceptible } \\
\text { acidity }\end{array}$ & Desirable & $\begin{array}{l}\text { Absence of } \\
\text { sourness }\end{array}$ & Desirable & like slightly \\
\hline $\begin{array}{l}\text { T2- } 150 \mathrm{~g} \text { fresh } \\
\text { immature "batuan" } \\
\text { fruit } \mathrm{L}^{-1} \text { tap water }\end{array}$ & $\begin{array}{l}\text { Slightly } \\
\text { brown }\end{array}$ & $\begin{array}{l}\text { Perceptible } \\
\text { acidity }\end{array}$ & Desirable & $\begin{array}{l}\text { Slightly } \\
\text { sour }\end{array}$ & $\begin{array}{c}\text { Slightly } \\
\text { desirable }\end{array}$ & $\begin{array}{c}\text { Like } \\
\text { moderately }\end{array}$ \\
\hline $\begin{array}{l}\mathrm{T} 3-200 \mathrm{~g} \text { fresh } \\
\text { immature "batuan" } \\
\text { fruit } \mathrm{L}^{-1} \text { tap water }\end{array}$ & $\begin{array}{c}\text { Creamy } \\
\text { white }\end{array}$ & $\begin{array}{l}\text { Perceptible } \\
\text { acidity }\end{array}$ & $\begin{array}{l}\text { Moderately } \\
\text { desirable }\end{array}$ & $\begin{array}{l}\text { Moderately } \\
\text { sour }\end{array}$ & Desirable & Like slightly \\
\hline $\begin{array}{l}\mathrm{T} 4-150 \mathrm{~g} \text { fresh } \\
\text { mature "batuan" fruit } \\
\mathrm{L}^{-1} \text { tap water }\end{array}$ & $\begin{array}{l}\text { Creamy } \\
\text { Slightly } \\
\text { brown }\end{array}$ & $\begin{array}{l}\text { Slightly } \\
\text { perceptible } \\
\text { acidity }\end{array}$ & $\begin{array}{c}\text { Slightly } \\
\text { desirable }\end{array}$ & $\begin{array}{l}\text { Slightly } \\
\text { sour }\end{array}$ & $\begin{array}{c}\text { Slightly } \\
\text { desirable }\end{array}$ & Like slightly \\
\hline $\begin{array}{l}\mathrm{T} 5-200 \mathrm{~g} \text { fresh } \\
\text { mature "batuan" fruit } \\
\mathrm{L}^{-1} \text { tap water }\end{array}$ & $\begin{array}{l}\text { Creamy } \\
\text { white }\end{array}$ & $\begin{array}{l}\text { Extremely } \\
\text { perceptible } \\
\text { acidity }\end{array}$ & $\begin{array}{c}\text { Slightly } \\
\text { desirable }\end{array}$ & $\begin{array}{l}\text { Moderately } \\
\text { sour }\end{array}$ & $\begin{array}{c}\text { Slightly } \\
\text { desirable }\end{array}$ & Like slightly \\
\hline $\begin{array}{l}\text { T6-150 g dry, powder } \\
\text { immature "batuan" } \\
\text { fruit } L^{-1} \text { tap water }\end{array}$ & $\begin{array}{c}\text { Slightly } \\
\text { brown }\end{array}$ & $\begin{array}{l}\text { Moderately } \\
\text { perceptible } \\
\text { acidity }\end{array}$ & $\begin{array}{l}\text { Slightly } \\
\text { desirable }\end{array}$ & $\begin{array}{l}\text { Moderately } \\
\text { sour }\end{array}$ & desirable & Like slightly \\
\hline $\begin{array}{l}\text { T7-200 g dry, powder } \\
\text { immature "batuan" } \\
\text { fruit } L^{-1} \text { tap water }\end{array}$ & $\begin{array}{l}\text { Slightly } \\
\text { brown }\end{array}$ & $\begin{array}{l}\text { Extremely } \\
\text { perceptible } \\
\text { acidity }\end{array}$ & Desirable & $\begin{array}{l}\text { Moderately } \\
\text { sour }\end{array}$ & $\begin{array}{l}\text { moderately } \\
\text { desirable }\end{array}$ & Like slightly \\
\hline $\begin{array}{l}\mathrm{T} 8-150 \text { g dry, powder } \\
\text { mature "batuan" fruit } \\
\mathrm{L}^{-1} \text { tap water }\end{array}$ & Brown & $\begin{array}{l}\text { Extremely } \\
\text { perceptible } \\
\text { acidity }\end{array}$ & Desirable & $\begin{array}{l}\text { Moderately } \\
\text { sour }\end{array}$ & $\begin{array}{c}\text { Slightly } \\
\text { desirable }\end{array}$ & Like slightly \\
\hline $\begin{array}{l}\text { T9-200 g dry, powder } \\
\text { mature "batuan" fruit } \\
\mathrm{L}^{-1} \text { tap water }\end{array}$ & Brown & $\begin{array}{l}\text { Extremely } \\
\text { perceptible } \\
\text { acidity }\end{array}$ & Desirable & $\begin{array}{l}\text { Extremely } \\
\text { sour }\end{array}$ & $\begin{array}{l}\text { Slightly } \\
\text { desirable to } \\
\text { extremely } \\
\text { desirable }\end{array}$ & Like slightly \\
\hline
\end{tabular}

physicochemical properties and nutrient composition of "batuan" fruits may differ according to fruit parts and maturity. Nevertheless, values obtained are comparable and even better than some conventional fruits used as souring agent reported in literatures. Thus, "batuan" fruits could be an inexpensive source of essential nutrients, vitamins and minerals that are abundant in the peel, seeds, immature, mature and the ripe fruits. The seeds which contain high crude fat $(54.72 \pm 0.34 \%$ dry weight) are potential sources of oil for food and industrial applications. Due to their high crude fiber and low total soluble solids, total sugar and carbohydrates contents, "batuan" fruits can be a potential raw material for the development of 
various low carbohydrate food products. Because of their comparable acceptability, the dried, powdered immature and mature "batuan" fruits may be used as a souring agent for domestic consumption, food industry and other applications. However, further studies must be done on "batuan" fruit samples from other geographic locations in order to confirm the current findings. Future studies on the identification of other nutraceutical compounds in "batuan" fruits, and in vitro as well as in vivo assessments on the efficacy of the "batuan" fruits in the prevention of several body disorders and diseases are to be investigated. Other valueadded products using "batuan" fruits together with safety assessments are to be pursued.

\section{ACKNOWLEDGEMENT}

The authors would like to thank the DA-BIOTECH Program and the Visayas State University for funding this research, faculty/staffs of DFST and DoPAC, and the Quevedo family for their extraordinary and generous help in this study.

\section{REFERENCES}

ADEKUNLE, A.I. and J.O. ADENIKE. 2012. Comparative analysis of proximate, minerals and functional properties of Tamarindus indica pulp and Ziziphusspina Christi fruit and seed. Greener Journal of Agricultural Science 2(1):21-25.

ADEOLA, A.A., OLUNLADE, B.A., OFOLABI, M.O., ADEOLA, O.O. and OW. IBITOYE. 2012. A comparative evaluation of the physical and chemical properties of Tamarind (Tamarindus indicus L.) seeds in Nigeria. Journal of Agricultural Research and Development 11(2):151-158.

ANONYMOUS. 2006. Batuan Puree. In: Wyatt's Kitchen. Accessed on July 27,2013 from: www.wayttskitchen.com/2006/12/7/batuan-puree/

[AOAC] ASSOCIATION OF ANALYTICAL CHEMISTS. 1980. The Official Methods of Analysis of the Association of Official Analytical Chemists. $13^{\text {th }}$ Ed. W. Horwitz (ed) Washington DC, USA. Pergamon Press. 
AJAYI, I.A., E. IFEDI and V.N. AGHANU. 2013. Amino acid analysis and preliminary toxicological evaluation of Garcinia mangostana seed cake in albino rats. Global J. of Sci. Front. Res. Chem. 13(1):16-22.

ATASIE, V.N. and T.F. AKINHANMI. 2009. Extraction, compositional studies and physico-chemical characteristics of palm kernel oil. Pakistan Journal of Nutrition 8(6):800-803.

BUTKHUP, L. and S. SAMAPPITO. 2011. Changes in physico-chemical properties, polyphenol compounds and antiradical activity during development and ripening of maoluang (antidesma bunius l. spreng) fruits. Journal of Fruit and Ornamental Plant Research 19(1):85-99.

CANAPI, E.C., AGUSTIN, Y.T.V., MORO, E. A., PEDROSA, E. JR. AND M.L.J. BENDAÑO. 2005. Coconut Oil. In: Bailey's Industrial Oil and Fat Products Sixth Edition. (ed.) Shahidi, F. John Wiley \& Sons, Inc. Hoboken, New Jersey 3:123-147.

COCHRAN, W.G. and G.M. COX. 1957. Experimental Designs. New York, London. John Wiley \& Sons, Inc.

COJUANGCO, G.O. 2012. Binukao-A source of my gastronomical treats. In: Inquirer Opinion. Accessed on July 26, 2013 from: http://opinion. inquirer.net/41012/binukau\#ixzz2YcY4mqGr.

CORONEL, R.E. 2011. Important and Underutilized Fruits of the Philippines. DA-BAR and UPLB. Manila, Philippines.

CORONEL, R.E. 1991. Tamarindus indica L. In: Verheij, E.W.M \& CORONEL, R.E. (eds) Plant Resources of South East Asia No. 2 Edible Fruits and Nuts. PROSEA Foundation, Bogor, Indonesia pp.298-301.

DE LA CRUZ, R.T. 2012. Binucao: the underutilized souring agent. BAR Chronicle. September 2012 Issue 13: 9

DEPARTMENT OF AGRICULTURE OF THE PHILIPPINES. 1995. Philippines: Country Report to the FAO International Technical Conference on Plant Genetic Resources (Leipzeg, 1996). Accessed on July 26, 2013 from w w w. fa o.org / file a d m in / te m plate / a g p ho m e / documents/PGR/SoW1/asia/PHILIPPINES 
EKHOLMA, P., REINIVUO, H., MATTILA, P., PAKKALA, H., KOPONEN, J. HAPPONEN, A., HELLSTROM, J. and M.L. OVASKAINEN. 2007. Changes in the mineral and trace element contents of cereals, fruits and vegetables in Finland. Journal of Food Components and Analysis 20:487495.

FEUNGCHAN, S., YIMSAWAT, T., CHINDAPRASET, S. and P. KITPOWSONG. 1996a. Tamarind (Tamarindus indica L.) plant genetic resources in Thailand. Thai Journal of Agricultural Science Special Issue 1: 1-11.

FEUNGCHAN, S., YIMSAWAT, T., CHINDAPRASET, S. and P. KITPOWSONG. 1996b. Evaluation of Tamarind cultivars on the chemical composition of pulp. Thai Journal of Agricultural Science Special Issue 1:28-33.

FLORIDO, H.B. and F.F. CORTIGUERRA. 2003. Lesser Known Edible Tree Species. Research Information Series on Ecosystem. 15(3):7-8.

GORINSTEIN, S., ZACHWIEJA, S., FOLTA, M., BARTON, H., PIOTROWICZ, J., ZEMSER, M., WEISZ, M., TRAKHTENBERG, S., and O. MARTIN-BELLOSO. 2001. Comparative content of total polyphenols and dietary fiber in tropical fruits and persimmon. Journal of Agriculture \& Food Chemistry 49:952-957.

KADAM, D.M., KAUSHIK, P. and R. KUMAR. 2012. Evaluation of guava products quality. International Journal of Food Science \& Nutrition Engineering 2(1):7-11.

KAUR, G., NAGPAL, A. and B. KAUR. 2006. Tamarind - Date of India. Science Tech Entrepreneur Dec 2006 Issue

MORTON, J. F. 1987. Bilimbi. p.128-129 In: Fruits of Warmer Climates. Accessed on September 4, 2013 from http://www.hort.purdue.edu /newcrop/morton/bilimbi.html

MORTON, J. F. 1987. Calamondin. p176-178 In: Fruits of Warmer Climates. Accessed on September 4, 2013 from http://www.hort.purdue.edu/ newcrop/morton/calamondin.html

MORTON, J. F. 1987. Guava. p.356-363 In: Fruits of Warmer Climates. Accessed on September 8, 2013 from http://www.hort.purdue.edu/ newcrop/morton/guava.html 
MORTON, J. F. 1987. Santol. p.199-201 In: Fruits of Warmer Climates. Accessed on September 4, 2013 from http://www.hort.purdue.edu/ newcrop/morton/santol.html

NAKASONE, H.Y., HAMILTON, R.A. and P.J. ITO. 1967. Evaluation of introduced cultivars of guavas. University of Hawaii Hawaii Farm Science 16: 4-6.

ONYEIKE, E. N. and G.N. ACHERU. 2002. Chemical composition of selected Nigerian oil seeds and physiochemical properties of oil extracts. Food Chemistry 77: 431-437.

PATIL, A.G., PATIL, D.A., PHATAK, A.V. and N. CHANDRA. 2010. Physical and chemical characteristics of Carambola (Averrhoa carambola L.) fruit at three stages of maturity. International Journal of Applied Biology \& Pharm Technology 1(2):624-629.

PAULL, R.E. and O. DUARTE. 2012. Tropical Fruits. (Specify publisher) $2^{\text {nd }}$ Ed. 2:123.

PRITCHARD, J.L.R. 1991. Analysis and properties of oilseeds. In: Analysis of Oilseeds, Fats and Fatty Foods (Ed.): J.B. Rossell and J.L.R. Pritchard. Elsevier Applied Sciences, London, New York. 127: 80-98.

REYES, G. 2011. Batwan's the best! In: Experience Negros Travel \& Lifestyle. Accessed on July 26, 2013 from: http://www.experiencenegros.com/ batwan-is-the-best/

SETIAWAN, B., SULAEMAN, A., GIRAUD, D.W. and J.A. DRISKELL. 2001. Carotenoid content of selected Indonesian fruits. Journal of Food Composition and Analysis 14:169-176.

SUN, B., RICARDO-DA-SILVA, J.M. and I. SPRANGER. 1998. Critical factors of vanillin assay for catechin and proanthocyanidins. Journal of Agriculture and Food Chemistry, 46 (10); 4267-427.

TAJANLANGIT, E.F.J. 2011. "Garcinia binucao" In: The Good Life. Accessed on July 26, 2013 from: http://www.visayandailystar.com/2011/January/ 12/goodlife.htm 
VALENCIA, C. 2013. Palawan's endemic fruits eyed for export. In: Philstar Business. Accessed on July 26, 2013 from:http://www.philstar.com/ agriculture/2013/02/03/904088/palawans-endemic-fruits-eyed-export.

VERHEIJ, E.W.M and R.E. CORONEL. 1999. Plant Resources of South-East Asia 2:Edible fruits and nuts. Third impression. Prosea Foundation, Bogor, Indonesia. Prosea 2:337.

VOĆA, S., DOBRIČEVIĆ, N., DRAGOVIĆ-UZELAC, V., DURALIJA, B., DRUŽIĆ, J., ČMELIK, Z. and M.S. BABOJELIĆ. 2008. Fruit quality of new early ripening strawberry cultivars in Croatia. Food Technology and Biotechnology 46: 292-298.

WENKAM, NS. 1990. Foods of Hawaii and the Pacific Basin. Fruits and Fruit Products Raw, Processed and Prepared. Vol 4 Composition, Research Extension Series 110. College of Tropical Agricultural \& Human Resources, University of Hawaii, Honolulu, Hawaii.

YAP, S.K.L. 2011. Characterization and lipid profile of malunggay (Moringa oleifera Lamk) seed oil. Unpublished BSChem Thesis. University of the Philippines Los Baños, Laguna, Philippines. 